\title{
USING GEOMATICS TO UNDERSTAND AND VALORIZE HERITAGE, THREE DIFFERENT CONTEXTS OF STUDY: SYRIA, ITALY, AND FRANCE.
}

\author{
E. E. K. Hanna ${ }^{1}$, A. Paonessa ${ }^{2}$ \\ ${ }^{1}$ Institut National de l'Histoire de l'Art; Pontificio Istituto di Archeologia Cristiana - elia.kashanna@yahoo.it \\ ${ }^{2}$ University of Cologne, Aix-Marseille University- alessio.paonessa@ gmail.com
}

KEY WORDS: Syria, MicMAc, Late antiquity, Lérins, Capo Don, Heritage under risk, Spatial analysis

\begin{abstract}
:
Such innovative meeting dedicated to Cultural Heritage: challenges, new perspectives, and technological innovation are 'vital' in order to exchange different experiences, needs, opportunities, and, above all, to find new approaches to preserve, at least, the memory of heritage for further generations. This paper includes some experiences accumulated throughout several topographic projects concerning Christianity during the Late Antiquity and Early Medieval Ages in northern Syria, in Liguria in Italy, and in Provence in France. Geospatial and Geomatics data have been used in these investigations, since 2007, thanks to the Pontifical Institute of Christian Archaeology of Rome, the National Institute for Art History in Paris, Nino Lamboglia Foundation, and Marc de Montalembert Foundation. The Geospatial data highlighted for the first time, after about a century of research, much un- published data about Syrian monasteries. One of our goals was to understand what the exact differences are from all points of view: time, results, and economic costs between Agisoft Photoscan and MicMac. The models of the two applications are well made, but we noticed that the model created by MicMac software is excellent, despite being an open source application. In 2017, due to the positive geomathic results during the last three seasons of our excavations on the site of Capo Don, the first Multimedial Exhibition Space (SEM) of the town Riva Ligure was inaugurated, thanks to Comune of Riva Ligure, and all research team members guided by professor Philippe Pergola. Geomatics is a powerful tool not only for preserving memories, but it is ideal for dissemination heritage on the public levels, exactly like the role of archaeology.
\end{abstract}

\section{TOPOGRAPHICAL FRAMEWORK}

Usually, it is very risky for the integrity and the transitional fluidity of the text to present the archaeological results of three geographically distinct territories, like the Syrian Limestone area, the Liguria region in Italy, and Provence in South-Eastern France. Although, they are very distant from a geographical point of view, however, between the second half of $4^{\text {th }}$ and the end of the $6^{\text {th }}$ century, they are distinguished by the same architectural and topographic development processes. Chronologically, these progressions have occurred, almost, simultaneously with some slight differences, due to geographical and/or political reasons.

According to the epigraphic sources, the Christianization of the rural Syrian Limestone region was started in the late $4^{\text {th }}$ and early $5^{\text {th }}$ century. Between the $5^{\text {th }}$ and $6^{\text {th }}$ centuries, the rural inhabited areas of the classical period of the region experienced a long period of transformation and expansion. In the $5^{\text {th }}$ century, temples were transformed into Christian worship spaces. From the later part of the $4^{\text {th }}$ century, hundreds of basilicas, chapels, and monasteries were built ${ }^{(1)}$. Among the second half of the $5^{\text {th }}$ and the first half of $6^{\text {th }}$ century, the quantity of churches erected was increased radically. The basilicas with three naves could have enormous dimensions: some may have had $30 \mathrm{~m}$ in length, which evokes the churches built in city centres of Syria. The settlements, also, knew an impressive demographic growth, that it led to an intensification with the construction of the residential facilities ${ }^{(2)}$.

Although the monastic phenomenon in Syria existed since the $3^{\text {th }}$ century, throughout the Late Antiquity it experienced a big prosperous period. Monasteries, hermitages and many stylite pillars were raised. Some of them were installed next to the

\footnotetext{
(1) Butler, 1929. Tchalenko, 1979. Tchalenko, 1990

(2) Tate, 1992, 305-314.
}

roman roads; others were located close to the secular settlements. It seems that monasticism has played an important economic, social and spiritual role in the region. Some monasteries were becoming pilgrimage centres due to the presence of holy monks or holy objects of public worship. Other monasteries were specialized in the production of olive oil because the present oil mill. The monasteries brought a lot of wealth into the region that can be interpreted today from the high architectural level of the structures of the monasteries ${ }^{(3)}$.

In Occident, the Christian monuments, during in the Late Antiquity, have reshaped the Roman rural landscape. The archaeology of rural landscape in Liguria and Provence restored a very similar image to the Syrian territorial reality. We have fragmentary archaeological data deriving from singular researches and emergency and didactic excavations conducted by various university teams, such as the Pontifical Institute of Christian Archaeology, the University of Genova, and the University of Aix Marseille.

The recent archaeological acquisitions in the field allow us to delineate with a certain precision the geography of the oldest rural ecclesiastical settlements in Liguria. Since the beginning of 2000, archaeology has highlighted important examples of Christian settlements of different types. There are the ruins of the baptismal-funeral basilica of Capo Don, Costa Balenae, near Riva Ligure $\left(6^{\text {th }} \text { century }\right)^{4}$, the Pieve del Finale $\left(5^{\text {th }}-7^{\text {th }}\right.$ century) $)^{(5)}$, San Paragorio in Noli (V-VI), Santa Maria of Vezzano $\left(5^{\text {th }}-6^{\text {th }} \text { century }\right)^{(6)}$, and San Venerio in Antonina, near Migliariana, in the territory of La Spezia ${ }^{(7)}$.

\footnotetext{
${ }^{(3)}$ E. K. Hanna, 2018, 7-80.

(4) Pergola et al., 381-412.

${ }^{(5)}$ Frondoni, 2003, 156-158.

${ }^{(6)}$ Frondoni, 2000, 153-184. Frondoni, 2003, 140-142.

${ }^{(7)}$ Frondoni, 2003, 137-138.
} 
In Liguria the insular monastic settlements are displayed on many islands: there are two oratories dating back to the $5^{\text {th }}$ century on the Bergeggi ${ }^{(8)}$ and Tinetto ${ }^{(9)}$ islands. Also on the Tinetto Island another worship building with two naves and three apses with cells in front of the building dated back from the $10^{\text {th }}$ to the $11^{\text {th }}$ century. Contemporary with the previous structures, there is another monastery located on the island of Tino, next to Tinetto, which consists of two pre-existent settlements, the oldest of which could be dated back to the $5^{\text {th }}$. $6^{\text {th }}$ century ${ }^{(10)}$. Since ancient times, the geographic formation of the area of Liguria, which is a totally mountainous territory, has always made moving around the area particularly problematic outside the roman main roads. In this context, it is not surprising to note that all archaeological vestiges of the Late Antiquity and Early Middle Age are located precisely next to the ports and official main routes. This does not mean that the mountains were not inhabited, but rather, some recent archaeological data has started to draw a new panorama of the rural Ligurian territory. For example, investigations after the year 2010 have confirmed that the fortified site of Campo Marzio has revealed stratigraphic layers dating back to the $7^{\text {th }}$ century. The site is a Byzantine fortification, located next to the Argentina river, on the byzantine borders with the Lombard kingdom ${ }^{(11)}$.

The nearby Provence region is one of the richest regions in Early Christian and Early Middle Ages of archaeological sites in southern Gaul. The influence of urban architectural models is particularly clear in rural ecclesiastical constructions on a stereotypical level. Many churches have been identified within the countryside of the region, dated between the $9^{\text {th }}$ and $12^{\text {th }}$ centuries, as well as the churches of Saint-Maximin and SaintHermentaire next to Dragignan, and Notre-Dame-du-Brusc in Châteauneuf-de-Grasse. They are also characterized by frequentative phases of the $6^{\text {th }}$ century ${ }^{(12)}$. All these structures have the same plan: a very large single nave, to which is attached a small baptistery located to the west. In this period, a main part of the classic villas already was abandoned in favour of the inhabited centres, positioned on the hills and between the mountains of the Maritime Alps. In this period, the phenomenon of perched villages was identified in the region, exactly between the late $5^{\text {th }}$ century and early $6^{\text {th }}$ century, as the site of SainteCandie ${ }^{(13)}$

From the end of the $4^{\text {th }}$ century, the presence of sarcophaguses with Christian decoration in the sites of Saint-Maximin, Celle, and Sannes, testifies to the burial of a Christian elite in these rural domains. Funeral structures claim that during the $5^{\text {th }}$ century and even more in the beginning of the $6^{\text {th }}$ century, the Christianization movements were intensified.

The monastic movements in Provence, according to the literary sources, rises with Saint Martin of Tours, toward the $4^{\text {th }}$ century, with the foundation of the two monasteries: Ligugé and Marmoutier. Those monasteries, soon, would become a lighthouse for all the monasticism in region because they donated many bishops to the cities southern Gaul. During the early part of the $5^{\text {th }}$ century, Saint Honorat, after a brief monastic experience in the East, had retired with his family into the islands of the archipelago of Lérins. The smallest island includes, even today, the abbey of Lérins, a fortified monastery and seven scattered chapels. These chapels have a large chronological arc: from the $9^{\text {th }}$ to the $14^{\text {th }}$ century.

\footnotetext{
${ }^{(8)}$ Bulgarelli 2003, 211-219. Frondoni, 1998, scheda 15.

${ }^{(9)}$ Frondoni, 1987, 265-274. Frondoni, 2003, 136-137.

${ }^{(10)}$ Frondoni, 2003, 134-136.

(11) Lamboglia, 1950, 48-49. Gamabro 2008, 108-110.

${ }^{(12)}$ Codou, 2013, pp. 126-130.

${ }^{(13)}$ Segura, 2015-2016, 25-32.
}

Under the chapel dedicated to St. Savior, remains of a preexistent mono-apse religious building and various adjacent rectangular cells, have been found. They were interpreted by Yann Codou as a hermitage of $5^{\text {th }}-6^{\text {th }}$ century with different occupation levels until the $12^{\text {th }}$ century ${ }^{(14)}$. If this interpretation is correct, this building would be the only insular monastery, until today, found in this part of the Mediterranean Sea. The ascetic ideal, so widely developed during the $5^{\text {th }}$ century by the Provençal foundations, spread among the population, especially thanks to the monks called to the episcopate that they spread the model in their diocese.

In the following papers, only some of our results will be summarized, achieved during the investigations of the team in the Mediterranean transboundary area: Syria, Italy, and France, related to geomatics and spatial analysis. All this research was scientifically directed by Philippe Pergola, research director in the French CNRS and professor at the Pontifical Institute of Christian Archeology in Rome. Some of these investigations are individual initiatives, others are planned research conducted through team work of doctoral and post-doctoral students. The funds used may have private origins as the archdiocese of the Syriac Orthodox Church of Aleppo, diocese of Ventimiglia, as well as Nino Lamboglia Foundation, direct by Alessandro Garrisi, field director of the excavations at archaeological site of basilica of Capo Don in Riva Liguria, and Marc de Montalembert foundation. Also some public funds obtained from the communes has been used.

\section{MICMAC: MODALITIES, EXPERIENCES, AND} RESULTS

The so-called MicMac software is developed by the French Institut National de l'Information Géographique et Forestière. It is, for the moment, the only multiplatform (Windows, Mac OS, Linux), and completely free solution for photogrammetry from tie points matching to meshing and texturing. Released under the license CeCILL-C, it is a free software as stated by the Free Software Foundation. It offers two ways to work: the first one, and the more preferable one, is the terminal, which is well designed and easily supports scripts in many languages to serialize operations; the other way is a GUI called CEREMA, which is not updated frequently with the last version dating back two years.

Of course when a graphic interaction is needed, e.g. when GCPs must be specified on photos or a mask drawn, it is available as a graphic solution to interact with the program. Community driven support is reachable on the dedicated forum (http://forum-micmac.forumprod.com/), or on the Reddit page (https://www.reddit.com/r/MicMac). On the GitHub website it is possible to download the source code, binaries (Windows and Mac), and a very good documented manual. Even though most parts of the documentation are in English, sometimes French may help to understand some other parts, which are not translated into English.

MicMac application has been part of an experiment in the Basilica of Capo Don 'Costa Balenae', since 2017. The project was carried out by the Pontifical Institute for Christian Archaeology and the Nino Lamboglia Foundation. In the occasion of the opening of one of the coffins, situated in the northern nave of the church, the team opted to use MicMac as a preliminary experiment. After a long elaboration with less than 60 photos, the dense cloud that resulted was composed of over 17.000.000 points, even though SIFT is not the best algorithm to elaborate very dense cloud points. After the internal orientation (Tapioca and Tapas), sparse and dense point cloud

(14) Codou, 2012, 77-81. 
(AperiCloud, and C3DC) were elaborated with the automatic processing. The final result (figure 1) was then processed in Meshlab with filter Poisson and transferring of the color attribute to the texture. The model was finally $3 \mathrm{D}$ printed by the CoDArchLab in Cologne.

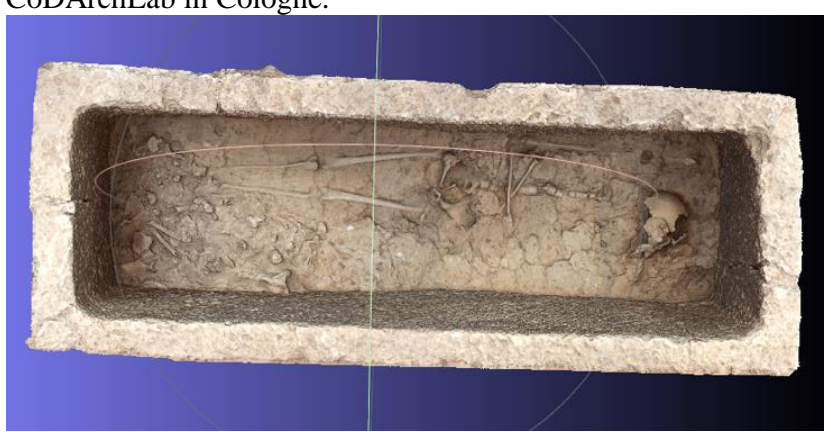

Figure 1. The printable coffin, the site of Capo Don 'Costa Balenae'.

The encouraging products drove the team to go further with the experiment. During the excavation of 2018, the team tried to survey every identified stratigraphic unit. The total number of surveys was about 20 with a total of 869 pictures, and with a resolution of $5184 \times 3456 \mathrm{px}$. All photos were taken with a Canon APS-C 600D photo camera hooked to a 3,3 m telescopic brace in carbon and equipped with a Sigma $10-20 \mathrm{~mm}$ (focal length $10 \mathrm{~mm}$ ).

It was not possible to survey every SU with MicMac, because of some problems due to the differences between the old and new gotten GCPs. These points sometimes gave us unpredictable results as translations and incorrect absolute position or orientation in some orthophoto mosaics. These problems were difficult to manage and they are still under investigation: the first hypothesis is a lack of GPS precision. Better results in this hard situation have been achieved with Pix $4 \mathrm{D}^{15}$, which was used in parallel to control and see differences in the results (figure 2). Even in those cases, it is our opinion that it is still problematic to have a correct stratigraphical sequence in subcentimetric precision without a denser and more flexible mapping with a Total Station.

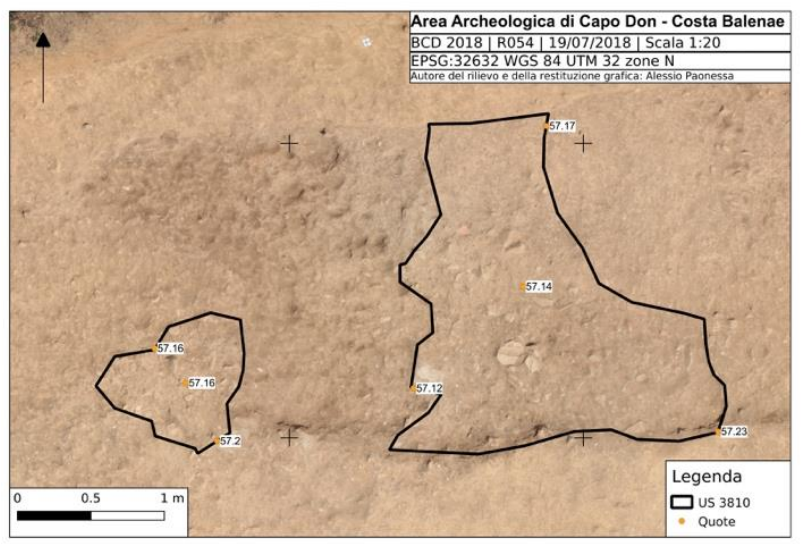

Figure 2. Example orthophoto mosaic for a single a Stratigraphic unite.

Furthermore, we are still looking for some new techniques to acquire precisely the $\mathrm{Z}$ factor, which is very important for archaeological investigations. Another tricky situation comes from the fact that some portions of the photos are less visible than the others, which is due to the contrast differences between

\footnotetext{
${ }^{15}$ To know more about Pix4D, see its price, and its features:
} https://www.pix4d.com/product/pix4dmodel the illuminated and shaded areas. At the moment we are looking to bypass this problem with some batch post-processing methods, resetting all the contrast and brightness values of the pictures. The weather was good along all the campaign, so we did not have to face problems with camera movements.

It is obligatory to present two more cases to get a full idea of the team's experiences and applications of the MicMac software. The other case of study was carried out within the project: les monastères des îles mineures de Provence et des archipels ligure et toscan de l'Antiquité Tardive au Moyen-Âge, scientifically directed by the Institut National d'Histoire de l'Art, and funded by Montalembert Foundation. The location is St. Honorat Island, the smallest island of Lérins archipelago, where two different chapels have been detected: the chapel of St. Michel and the Trinity chapel.

In the case of St. Michel chapel, it proceeded to a complete 3D model of the foundations, which are still visible on the path next to the little harbor. The chapel is unpublished edifice; it is still waiting to be dated by future studies.

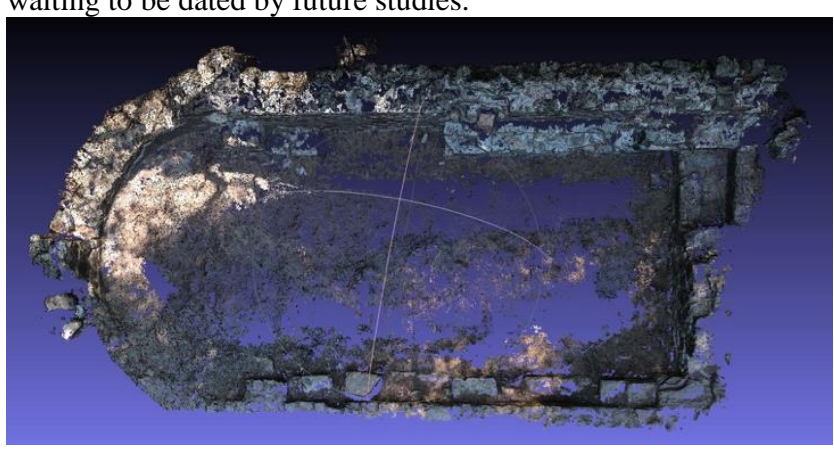

Figure 3. Dense cloud, St. Michel Chapel.

During the survey, the team had some difficulties because of the high movements of the trees by the strong blowing wind. Some rendering problems were met on the areas partially exposed to the sun. The total taken photos is 164 on both sides of the foundations, even on the dark side under the shadows, which is partially unreadable. The procedure is similar, as the equipment (lens Canon 18-55mm, focal length $30 \mathrm{~mm}$ ), is similar to the one used with the sarcophagus in Riva Ligure and completely automatic. The final treatment for mesh and texture was made with Meshlab (figure 3). As expected, the areas where the shadows were not static gave us a mesh with a big amount of noise. While, where the shadow was stable, the team has seen a high resolution level on the final texture.

Finally, the photogrammetric process is a serial process; therefore, an error committed in one phase has repercussions on the followings phases. The photogrammetric work have to be performed by people, who proceed according to the theoretical or empirical rules, guaranteeing the metric rigor of the results. Any error of the principles of photogrammetry, from the acquirement of the images to the preparation of the orthofo mosaic, is fatal and negatively affects the successive phases of the work. Therefore, a careful planning phase and a verification phase are appropriate at the end of each work phase.

\section{DRONES AND PHOTOGRAMMETRY}

For almost a century the aerial photography was the only tool for medium and large extensions of territory cartographic production at a fairly high cost. Finally, starting from a few years ago and thanks to the drones of medium-low cost, it could easily produce accurate maps of different types with automated systems. The latest generation of drone sensors is able to obtain high-resolution images which, when combined in suitable fashion, produce accurate $3 \mathrm{D}$ models that prove to be precise 
and suitable for measurement and stocked with a wealth of texture and detail.

Another experiment of the team, on the site of Capo Don, is the realization of a photogrammetric model of the investigated areas using a Dji Phantom IV drone, thanks to the generous funding of the Marc de Montalembert Foundation. The surveyed area measures $40 \times 30 \mathrm{~m}$. The flight was programmed with the Pix4Dcapture application ${ }^{16}$, the overlapping followed with a scheme characterized by $80 \%$ of longitudinal strips, and $60 \%$ of cross-strips, all with nadiral shots; the altitude is $7 \mathrm{~m}$ above the suface level. GDS (Ground Sampling Distance) was $0.15 \mathrm{~cm} /$ px and the drone speed did not exceed $3 \mathrm{~m} / \mathrm{s}$. The maneuvers of the drone were great, although there was a strong wind. The duration of the flight did not exceed 10 minutes, $50 \%$ of the battery was used with all active functionalities.

As for the GCPs points, we used the previous GCPs points used during the excavation campaign. Obviously this has compromised the accuracy of some areas without GCPs. The photos taken were about 40 frames. In this case, we used Agisoft Photoscan with an Educational License to see the differences with MicMac. The final product was of high quality, although it has been noticed that there is a lateral destruction of the orthophoto mosaic (figure 4).

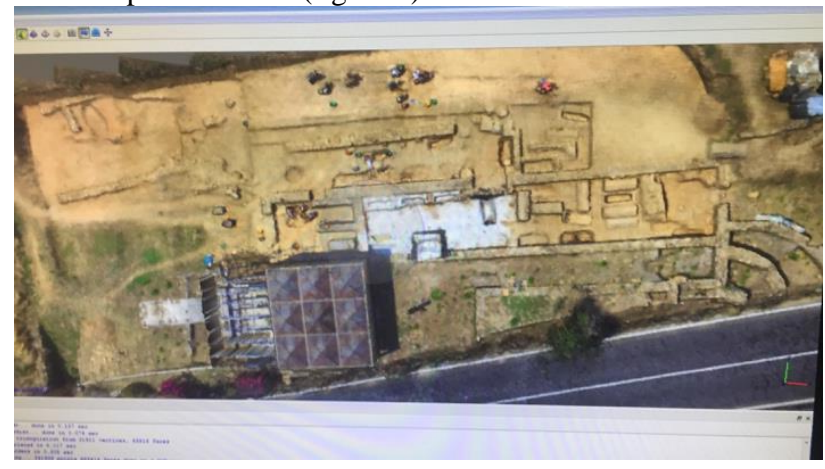

Figure 4. Mesh, the site of Capo Don 'Costa Balenae'.

The other drone survey is that on the site of Trinity chapel, in the St. Honorat Island to achieve all parts of the western facade with high precision. After a first attempt using the integrated GPS of drone that gave us bad results because of the lack of precision, we decided to align the wall through the manual rectification available in MicMac with the commands: SaisieMasq, SaisieBasc and SBGlobBascule. The 120 photos have been taken with a DJI Phantom IV and its photocamera (35mm equivalent), giving as result a very detailed orthophoto mosaic and DEM (figure 5).

The last example to present in this meeting is a relief made by the drone for a part of the south facade and the two apses of the Trinity chapel. For the reconstruction of the building, the drone performed a semi-circular manual flight to take photograms with the drone's camera inclined at $45^{\circ}$. The height of the highest strip is $6 \mathrm{~m}$, while the lowest one does not exceed 1.20 $\mathrm{m}$. Six-seven strips have been made at different levels, but the distance between drone and the structure was constant, $3 \mathrm{~m}$, in such way that the focal distance remained the same in all images. Particular care has been taken to overlap horizontal images, which is $70-80 \%$, while the lateral overlap is at least $70 \%$ : this was necessary because in the case of automatic image processing, three homologous points belonging to the same object must be visible on 3 different images.

\footnotetext{
${ }^{16}$ To know more about Pix4D visit, its functions and its futures: https://www.pix4d.com/product/pix4dcapture/
}

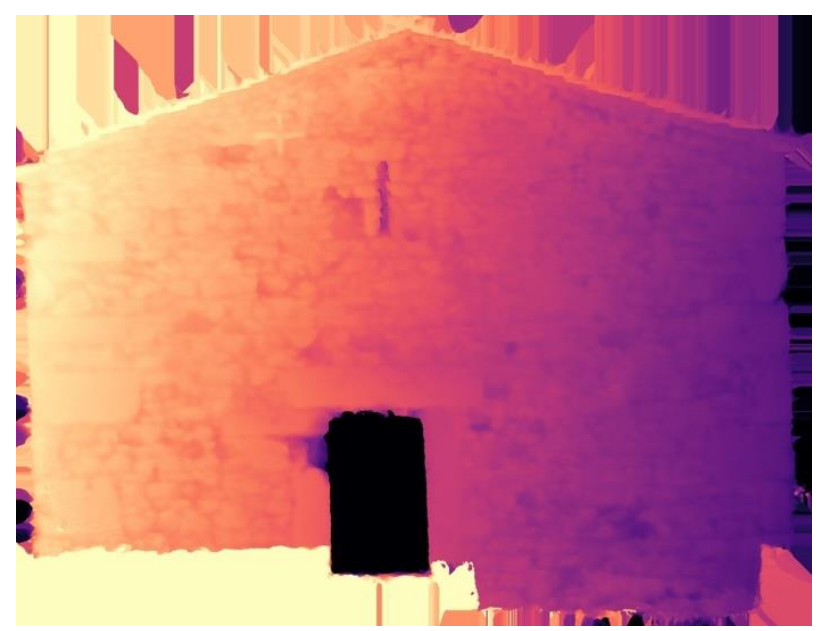

Figure 5. DEM, Trinity Chapel.

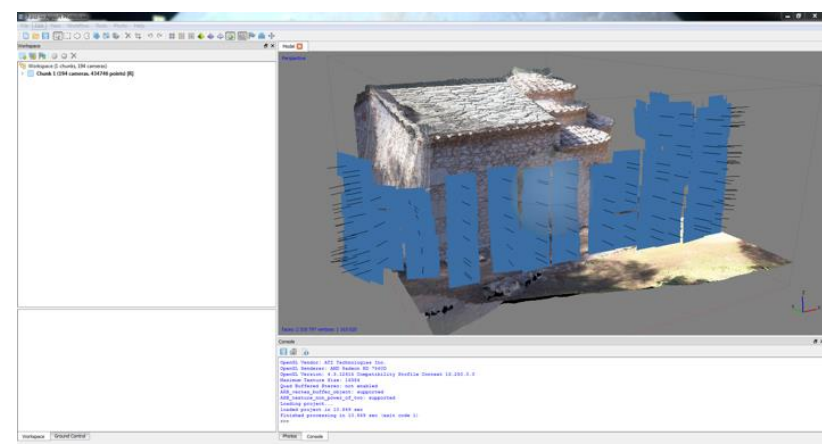

Figure 6. Drone's strips system, Trinity Chapel.

They shot about 194 images. The 3D model was developed with Agisoft Photoscan. The produced model was very good, despite the shadows of the surrounding trees, but thanks to the absence of the wind, such shadows did not influence the result (figure $6)$.

The first consideration, making use of our experiences with drone photogrammetry, is that all input data must be as constant as possible. In the case that the surveyed sites have strong altitude differences, the camera has to fly at the same altitude; otherwise, the GSD will vary greatly within the same model, decreasing its metric reliability. What is really important to maintain, is not the constancy of the flight altitude in comparison to the point of take-off, but the constancy of the altitude of flight from the object that must be surveyed. Therefore, it will be necessary to effect, many times, the flights piloting in manual; so it will be necessary to operate the flights, many times, flying manually. Therefore, it is better to avoid as much as possible the pre-programmed flights, because the drones flight-planning software does not precede that must be detected and the result which we want to achieve. Moreover, they do not always offer the possibility of varying the flight altitude along the route.

The longitudinal strips must be increased to prevent the fact that the lateral destruction falls on the portion to be surveyed. Generally, it has been noticed that it is necessary to increase especially the crossed strips in the presence of objects in elevation, such as buildings.

In the case of archaeological excavation sites, the ideal time to fly the drone is midday or at sunset to avoid the formation of the shadows that in some way compromise the photogrammetric model. In the case of a photogrammetric survey of buildings trapped between trees or other edifices, it is necessary to choose the time with the least amount of shadows as possible. The wind does not influence the drone's camera, but it could play a fatal 
role for the realization of the photogrammetric model in the case of tree shadow movements.

The drones make it possible to acquire data for photogrammetric applications in a simple and economic way. Like most other geomatics techniques, drones and digital photogrammetry are not self-sufficient: integrations with other techniques are always necessary in order to make the process more and more complete, effective, and economical.

The advantages of the drone are many: from the cost of purchase and maintenance, to the missions carried out autonomously, to the high maneuverability of the drone. The drone is the ideal tool for surveying in dangerous situations and in inaccessible areas.

\section{SPATIAL ANALYSIS THE LIMESTONE SYRIAN REGION CASE}

The Syrian Limestone area is a mountainous region, suited around $45 \mathrm{~km}$ north-western of Aleppo. It is composed from seven different mountains, narrow gorges, plateaus, very few water sources, and some small cultivable stains scattered everywhere in the territory. Two Roman roads also cross the territory: one of them was built during the Aurelian period, early of $2^{\text {end }}$ century, while the existence of the second Roman road is attested within the works of Theodoret of Cyrus, bishop of Cyrus, before the first half of the $5^{\text {th }}$ century.

Since the $19^{\text {th }}$ century, the archaeologists have recognized more than 800 archaeological sites concentrated in an area of $3 \mathrm{~km}^{2}$. It can be calculated around $266 \mathrm{~m}^{2}$ of free space usable for each single settlement. The restricted free areas are not only detectable outside the towns, but it is also a common feature inside the towns. Every settlement may contain from 10 to 109 structures interpreted as houses. It also could hold two or three basilicas and one or two baptisteries attached to the churches. Other constructions are thermal baths, cisterns, oil mill, inns, etc.

In 2010, in the occasion of my $\mathrm{PhD}$, directed by Professor Philippe Pergola, research director in the French CNRS and professor at the Pontifical Institute of Christian Archaeology in Rome, a survey campaign was launched with a duration of three months which was financed by the kidnapped archbishop of the Syriac Orthodox Church of Aleppo: Mar Gregorios Yuhanna Ibrahim. It had to affront different concerns inherent to the most effective and innovative methodology to be followed during operations in the field, according to available funds, and around bureaucratic and territorial restrictions. The first problem was how to collect the territorial and archaeological data in an exhaustive way. To solve this problem, we opted for a Trimble R6 Model 4 GNSS Rover UHF $450-470 \mathrm{MHz}$, with a centimeter-level accuracy, provided by the superintendents of Idleb. Unfortunately, to collect more geomatic data, even if the team was furnished by a drone, we couldn't use it because of governmental limitations.

To analyse the territory from point of view of geomorphology, we used some digital elevation models (DEM) from two combined sources. We utilized the first and second version of ASTER Global Digital Elevation Model, which, today, is one of the most important open source platforms on the market ${ }^{(17)}$. I noticed that in version 2 , the horizontal and vertical accuracy was increased as a horizontal resolution. This version is also distinguished by a reduced presence of artifacts and more realistic values over bodies of water. In 2015, two years before the end of reduction of my $\mathrm{PhD}$, it also used STRM data (Shuttle Radar Topography Mission). It is highest-resolution

(17) For more information about features, and utilization of STRM data: https://asterweb.jpl.nasa.gov/gdem.asp topographic data generated from NASA's Shuttle Radar Topography ${ }^{18}$. Most voids are filled with elevation data from the ASTER GDEM2.

All the steps of the present spatial analysis, could be performed in both the softwares of ArcGis and QGIS. At the conclusion of this paragraph, the reader will find a complete table of all the used commands in both software products.

DEM data, before being used, should be prepared for utilization, because it often presents some empty cells without metric values (no-data pixel). Voids are often caused by water bodies, class type selection, or exclusion. Consequently, the first step before starting the spatial analysis is to fill these gaps by a specific process. The tool in both softwares uses the inverse distance weighting. It is generally not so great for interpolating a raster from sparse point data. Obviously, there are other more complex and less automatic ways to close voids, as for example: the Delta Surface Fill Method (DSF) ${ }^{19}$.

The first real phase of the spatial analyses is to create a slope representation for the region. Slope represents the rate of change of elevation for each digital elevation model cell. It calculates the angle of inclination to the horizontal. It's the first derivative of a DEM. The other file to create is the aspect of the terrain data, which also derives from a raster surface. The aspect identifies the downslope direction of the maximum rate of change in value from each cell to its neighbors. It is useful to calculate the solar illumination for each location in a region as part of a study to determine the diversity of life at each site, to find facing slopes, and to identify flat areas appropriate for the installation of settlements or agriculture (figure 7).

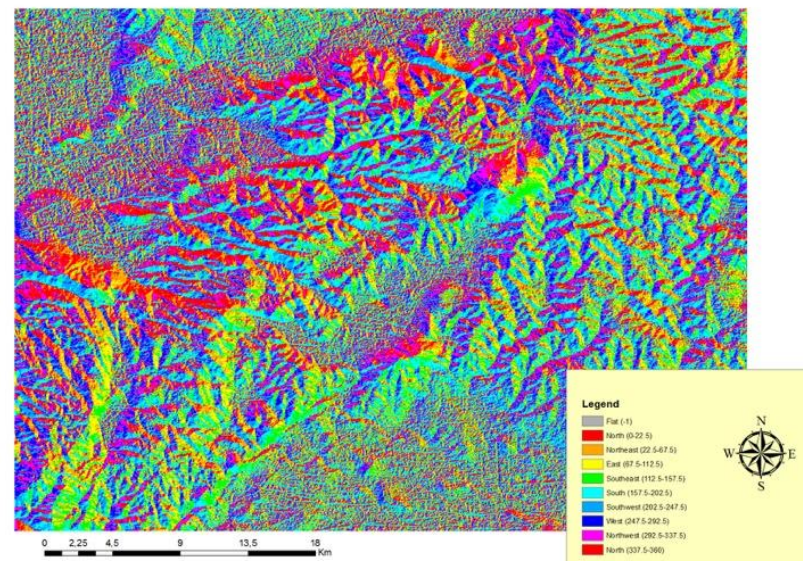

Figure 7. Aspect layer, Syrian Limestone Region.

Overlaying the Slope and Hillshade results, with a $33 \%$ transparency, and combining them with the monastic settlements' GPS points, it was possible to highlight a lot of unpublished information. The geostatistical information confirms that the main part of the monasteries of the region are built on the top of the hills or on their slopes, while the monasteries built on the plateau areas are so limited (figure 8). More than $43 \%$ of the monasteries are installed on the tops of the hills, $27 \%$ of the analyzed monasteries are located on the slopes of the hills, and $11 \%$ are located in the valley bottoms and plateaus. The remaining $11 \%$ of monasteries are still waiting to be more investigated.

\footnotetext{
18 For more information about features, and utilization of STRM data: https://www2.jpl.nasa.gov/srtm/

${ }^{19}$ Burrough, McDonell, 1998.
} 


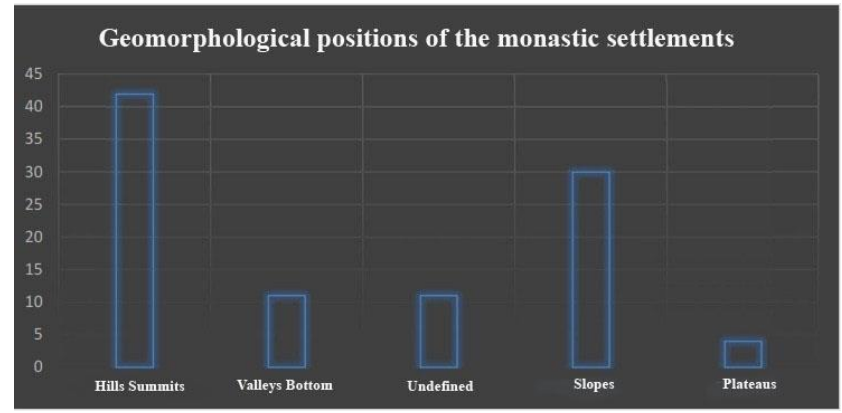

Figure 8. Geomorphological positions of the monasteries. After extrapolating the contour layer from the DEM with the appropriate command, we have proceeded to the analysis of the altitudes on which these monasteries had been erected. The mathematical results are listed in table 1 .

\begin{tabular}{|c|c|}
\hline Type & Altitude in \\
\hline Medium & 467 m.a.s.l. \\
\hline Standard Deviations & 658 m.a.s.l. \\
\hline Minimum & 327 m.a.s.l. \\
\hline Maximum & 588 m.a.s.l. \\
\hline
\end{tabular}

Table 1. Altitude of monasteries.

The spatial analysis relating to the distances between monasteries and villages, using Near tool in ArcGis or Distance Matrix in QGIS, has been confirmed: $84 \%$ of the total monasteries are located not more than $2 \mathrm{~km}$ from the nearest town, while more than $53 \%$ of the monasteries are installed within $1 \mathrm{~km}$ from the nearest settlement ${ }^{20}$. The mathematical results are listed in table 2 . The explanation of the curious proximity between the monasteries and the agglomerations could be due to possible economic and religious-social relations between the monastic centers and the inhabited centers.

\begin{tabular}{|c|c|}
\hline Type & Distance in $\mathbf{~ k m}$ \\
\hline Medium & 0.92 \\
\hline Standard Deviations & 0.65 \\
\hline Minimum & 0.03 \\
\hline Maximum & 2.21 \\
\hline
\end{tabular}

Table 2. Distance between monasteries and villages.

Within the topographical research project, such as the limestone region, where there is a dense quantity of archaeological sites, the analysis of visibility is particularly important in order to know the visibility of monastic settlements with respect to the surrounding landscape and the secular settlements (Figure 9). The visibility analysis is carried out by locating a set of possible points of view on the cartographic base and simulating the views from these points. This technique is a generalized analysis, based on the relations of the entire surrounding territory and the examined archaeological sites, in order to provide objective elements for the evaluation of the territory and its structures.

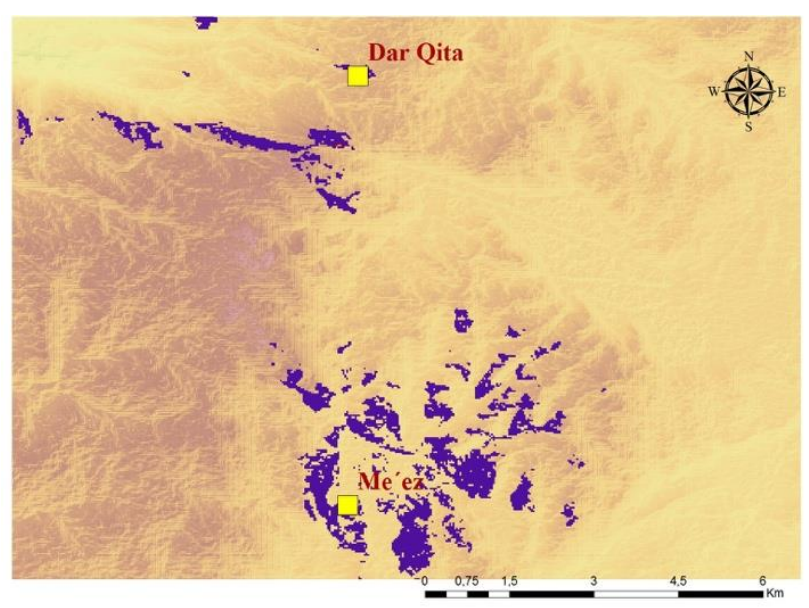

Figure 9. Visibility, example of the sites Dar Qita and Ma'ez.

The geo-morphological observation has brought to light further data, which is very essential to understand the monastic topography in this part of Syria. Not only the monasteries are installed next to the secular villages and main Roman roads, but also they are also located in the highest points of the territory around the settlements in such way as to be visible to the population. The statistic indicates that $91 \%$ of the monasteries are visible at least from one or more settlements.

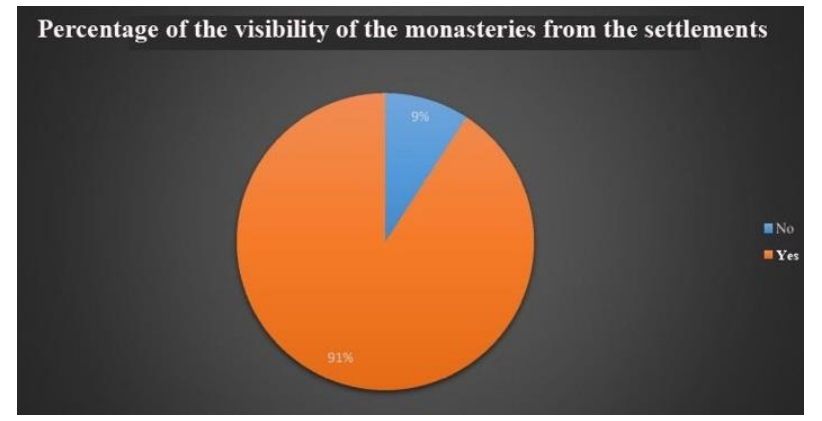

Figure 10 - Percentage of the monasteries from the settlements.

The following table (table 3) shows all the used commands for the spatial analysis of the Syrian region within both software products:

\begin{tabular}{|c|c|c|}
\hline Application & ArcGis & QGIS \\
\hline Fill DEM & $\begin{array}{c}\text { Windows }->\text { Add Function - } \\
>\text { Identify Function -> Insert } \\
\text { Function }->\text { Elevation Void } \\
\text { Fill Function }\end{array}$ & $\begin{array}{c}\text { Raster -> Analysis -> } \\
\text { Fill nodata }\end{array}$ \\
\hline Slope & $\begin{array}{c}\text { Arc Toolbox }->\text { Spatial } \\
\text { analysis tool }->\text { Surface -> } \\
\text { Slope }\end{array}$ & $\begin{array}{c}\text { Raster -> Analysis -> } \\
\text { Slope }\end{array}$ \\
\hline Aspect & $\begin{array}{c}\text { Arc Toolbox }->\text { Spatial } \\
\text { analysis tool -> Surface -> } \\
\text { Aspect }\end{array}$ & $\begin{array}{c}\text { Raster -> Analysis -> } \\
\text { Aspect }\end{array}$ \\
\hline Contour & $\begin{array}{c}\text { Arc Toolbox }->\text { Spatial } \\
\text { analysis tool }->\text { Surface }-> \\
\text { Contour }\end{array}$ & $\begin{array}{c}\text { Raster -> Extraction -> } \\
\text { Contour }\end{array}$ \\
\hline Visibility & $\begin{array}{l}\text { Arc Toolbox -> Spatial } \\
\text { analysis tool -> Surface -> } \\
\text { Viewshade } \\
\text { And Arc Toolbox -> Spatial } \\
\text { analysis tool -> Surface -> } \\
\text { Observer Points }\end{array}$ & $\begin{array}{c}\text { Raster }->\text { Viewshed } \\
\text { Analysis -> Viewshed } \\
\text { Analysis }\end{array}$ \\
\hline Proximity & $\begin{array}{l}\text { Arc Toolbox }->\text { Analysis } \\
\text { Tools }->\text { Proximity }->\text { Near }\end{array}$ & $\begin{array}{c}\text { Menu } \rightarrow \text { Analysis } \\
\text { Tools -> Distance } \\
\text { Matrix }\end{array}$ \\
\hline
\end{tabular}

Table 3. Commands in ArcGis and QGIS.

${ }^{20}$ E. Kas Hanna 2018, 5-80. 


\section{GEOMATICS APPLICATION ENVIRONMENTS: EXAMPLES}

In the last years, geomatics has stimulated and continues to inspire the evolution of more advanced technologies: newer, faster, smaller, and more accurate instruments capable of providing complete three-dimensional data. On the other hand, procedural evolution makes possible the quick and especially automatic extract of the requisite information while innovation in spatial storage techniques (GIS) allows us to propose numerous final products that are easier to read and use for effectively facing the planning processes in the area of protection and valorization of cultural heritage. The potential ways to use Geomatics are limitless as the technological frontier continues to move forward. Digital supports are always cheap and easy for technical, educational, or recreational purposes.

Assessing the archaeological sites is an activity aimed to promote and to understand the values expressed by cultural heritage while investing, mainly, the profits deriving from the protection. It is ideal for cultural heritage, for documentation, and for 3D modelling of archaeological sites from highresolution images. Geomatics has a role of service aimed to the mere acquisition of metric data to better interface with other disciplines that apply to the study and preservation of heritage. The 3D surveys could be used for the investigations and the restoration projects of the archaeological buildings. The 3D survey technologies are useful to monitor the process of physical and structural deformation and degradation of the archaeological monuments. So, geomatics could be essential to planning in a conscious way, and at the most opportune moment, any requisite interventions on things that are subject to risk of destruction in some way. Geomatics techniques must in the future contribute effectively to the implementation of specific databases related to the mapping of Cultural Heritage under a risk ${ }^{21}$

The heritage resources of Syria, unfortunately, are largely unknown. This is a natural consequence of the lack of a comprehensive record of sites, monuments, and significant finds. This makes heritage assets vulnerable to loss or change through conflicting land use and unsympathetic development. Many archaeological monuments in Syria have been lost forever, such as the triumphal arch, several temples of Palmira, and the baths and the markets of the medieval city of Aleppo. The sites of the Syrian Limestone region have suffered many irreparable damages: certain sites have been erased with mechanical means or heavy missiles, such as the case of the Esh-Sheikh Barakat temple (figure 11).

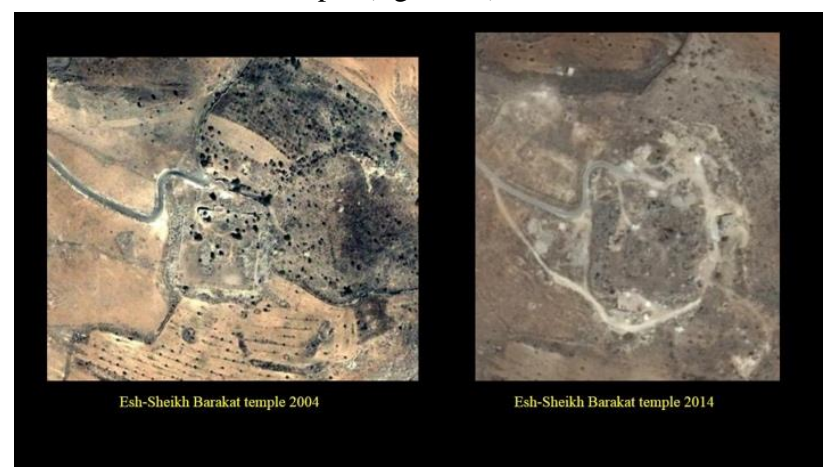

Figure 11. Esh-Sheikh Barakat temple 2004 - 2014.

Fortunately, for the temples and the triumphal arch of Palmyra there are $3 \mathrm{~d}$ reconstructions, faithful to the originals, made with the laser scanner and lidar, but unfortunately, it can't be said for

\footnotetext{
${ }^{21}$ Brumana, Monti 2004.
}

the destroyed sites of the Limestone region. Therefore, in the future the building of a National Heritage Inventory will need to be placed at the very top of the agenda quite simply to enable the Department to accomplish its role in Law.

One of the methods of application of geomatics, used by our research group, has been in the field of the divulgation of the archaeological heritage on the public level. In 2017, due to the positive geomathic results during the last seasons of our excavations on the site of Capo Don, the first Multimedial Exhibition Space (SEM) of the town Riva Ligure was inaugurated thanks to Comune of Riva Ligure, Nino Lamboglia Foundation, and all research team members guided by professor Philippe Pergola. SEM is an interactive museum where all the most important findings of the Capo Don site are present, like a tombstone of Mary and its Latin inscription (figure 12).

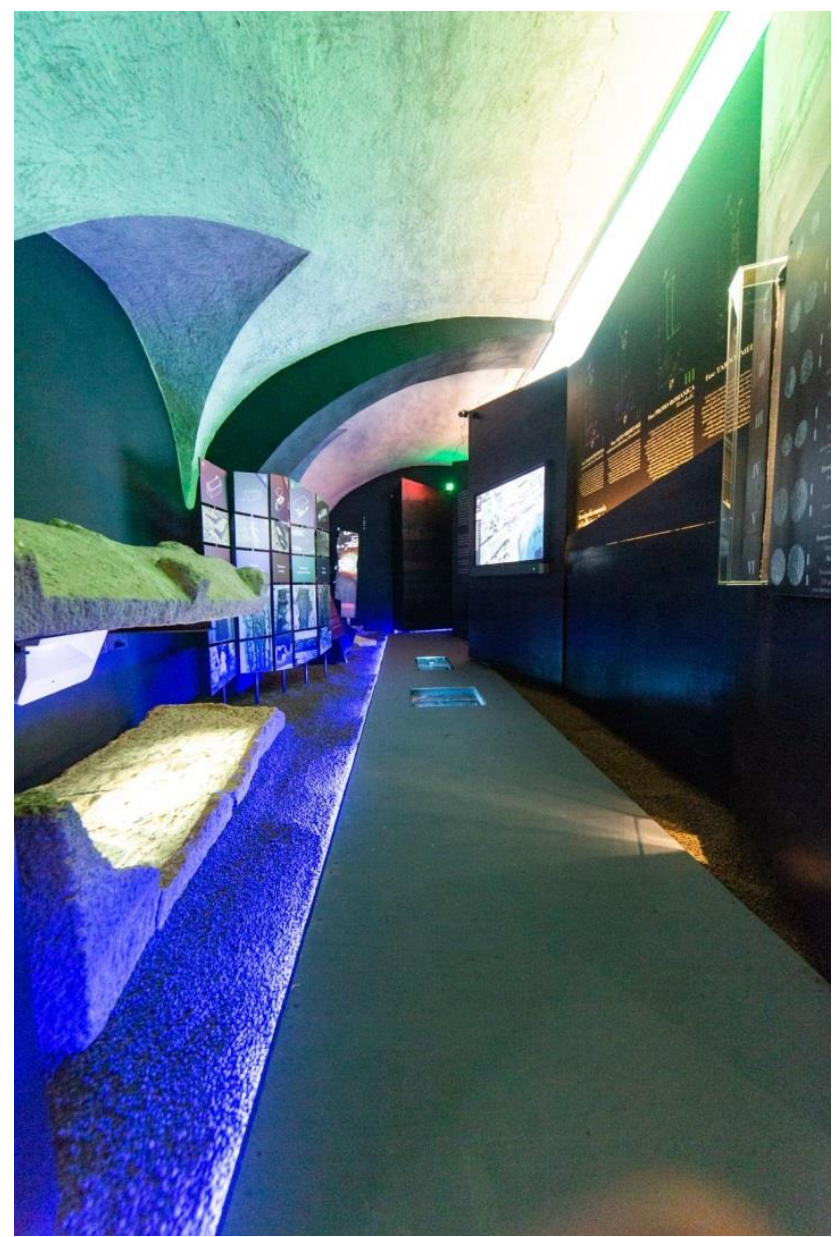

Figure 12. SEM, comune of Riva Ligure (IM). Photo by Alessandro Bonaldo

After the opening day of this museum, the level of interest in the population for the Capo Don site has progressively grown. For the next five months after the launch day, SEM received about 4000 visitors, and tourists from all ages and of different interests. Consequently, the interactivity of the museum has pushed the people to visit the site in reality that is located about $1.5 \mathrm{~km}$ outside of the village.

Another important role that geomatics may play is in the pedagogical field: printing the photogrammetric models of buildings, objects, and other staffs for pedagogical purposes, both for specialists, and for people of all the interests, and all ages. It is true that these printers are currently very expensive; however, thanks to the technological advancement of these 3D printers, they will soon be easily accessible. 
The geomatics documentation of movable and immovable goods is suitable also to study purposes, thanks to the fact that their products are nowadays digital which allows a metric and also a qualitative description that can make use of different survey tools that can be interfaced with each other.

It is now clear that we are today in the Digital era, geomatics should use it on a larger scale especially for the conservation of cultural heritage, because it is able to offer a wide range of instruments and methodologies, characterized by a high degree of innovation and technology. Looking critically toward this vast panorama, it is possible to use geomatics more effectively, like a 'virtual archaeology', to create new technologies for reason of safeguarding the historical and artistic heritages.

\section{REFERENCES}

Brumana R., Monti C. 2004. La carta del rischio del patrimonio culturale in Lombardia. Guida per la georeferenziazione dei beni storico-architettonici. Guerini e Associati, Milano.

Bulgarelli, F., 2003. Ritrovamenti di età romana nell'isola di Bergeggi: alcune riflessione, in Des îles côte à côte : histoire du peuplement des îles de l'Antiquité au Moyen Âge (Provence, Alpes-Maritimes, Ligurie, Toscane) [Actes de la table-ronde de Bordighera, 12-13 décembre 1997], Bordighera, 211-219.

Burrough, P. A., and McDonell, R. A., 1998. Principles of Geographical Information Systems. Oxford University Press, New York.

Butler, H. C., 1929. Early churches in Syria: Fourth to seventh centuries. Princeton monographs in art and archaeology, Princeton.

Codou, Y., 2013. L'Antiquité Tardive en Provence (IV $-V I^{e}$ siècle). Naissance d'une chrétienté. Centre Camille-Jullian, BiAMA Hors Collection, Aix en Provence.

Codou, Y., 2012. Monuments de Nice et des Alpes-Maritimes, Congrès Archéologique de France. Société Française d'Archéologie, Paris, 77-81.

E. K. Hanna, E., 2018. Il monachesimo e la topografia monastica nella regione del Massiccio Calcareo siriano, in $O C P, 84$, fasc. I, 7-80.

Frondoni, A., 1987. Archeologia in Liguria. III, 1-2: scavi e scoperte 1982-86, Soprintendenza archeologica della Liguria, Genova, 403-406.

Frondoni, A.,1998. Pieve dei cappuccini, in Archeologia Cristiana in Liguria, Soprintendenza archeologica della Liguria, Genova, scheda 11.

Frondoni, A., 2003. Gli scavi e le fasi edilizie di Santa Maria di Vezzano. Introduzione alle indagini archeologiche, in La chiesa romanica di Santa Maria di Vezzano Ligure: un edificio ritrovato. Atti del convegno di studi, Vezzano Ligure, 26 ottobre 1996, Giornale Storico della Lunigiana XLVI-XLVIII, La Spezia, 151-184

Frondoni, A., 2003. Chiese rurali fra V e VI secolo in Liguria. In Brogiolo, J-P., Le chiese rurali tra $V$ e VI secolo in Italia settentrionale e nelle regioni limitrofe. $9^{\circ}$ Seminario sul tardo antico e l'alto medioevo, Società archeologica padana, Mantova, 156-158.
Gamabro L., Pegola Ph., Benente F., 2008. Campagna di ricerche archeologica a Campomarzio (Taggia), in Archeologia in Liguria, III, 108-110.

Lamboglia N., 1950. Scavi nel castello di Campomarzio (Taggia), in RIngIntem, Bordighera, 1, 48-49.

Segura, J-A., 2015-2016. De nouvelles découvertes sur l'habitat de hauteur alto-médiéval de Sainte-Candie (Roquebrune-surArgens, Var), in Revue du Centre Archéologique du Var, 25-32.

Tate, G., 1992. Les campagnes de Syrie du nord du IIe au VIIe siècle : un exemple d'expansion démographique et économique à la fin de l'Antiquité, tome I. Librairie Orientaliste Paul Geuthner, Paris, 305-314.

Tchalenko, G., 1979. Églises de village de la Syrie du Nord. Bibliothèque Archéologique Et Historique, Paris.

Tchalenko, G., 1990. Églises Syriennes à bêma. Bibliothèque Archéologique Et Historique, Paris.

Pergola, Ph., Garrisi, A., Cagnana, A., Gambaro, L., Dellù, E., 2014. La chiesa battesimale e funeraria di Capo Don a Riva Ligure alla luce dei risultati della campagna 2014. In RAC, 90, Vatican City, 381-412.

Smith, J., 2000. Remote sensing to predict volcano outbursts. Int. Arch. Photogramm. Remote Sens. Spatial Inf. Sci., XXVIIB1, 456-469. 